\title{
"dunkel hell dunkel": Enzensberger's Two Piranesi Poems
}

\section{W.S. SEWELL}

Giovanni Battista Piranesi (1720-1778) was an artist who signed his work 'architetto Veneziano', but who spent the major part of his life in Rome and whose talents as an architect were never fully utilized. During his lifetime and subsequently he has received due recognition as a craftsman without peer in his chosen field of etching and engraving. He also achieved considerable commercial success, since his series of views of Rome and of its antiquities, the Vedute di Roma and the Antichità romane, were much sought after by the wealthy of Europe, who were just developing a taste for tourism and were as anxious as their modern counterparts to preserve some record of their travels. However, it is a series of a mere sixteen etchings entitled Carceri d'Invenzione ('Imaginary Prisons'), unique in Piranesi's output and indeed in 18th century art, which has fascinated the Romantic and the 20 th century mind in particular. With their dramatic play of light and shadow, their bewildering perspectives and their hints at the infinite, the Carceri have, as John Wilton-Ely suggests, "provided a series of visual analogies for the phenomena of disturbing imaginative experiences"; 1 and references to them may be found in the work of a number of writers. From Coleridge's description of the series alone Thomas de Quincey in his Confessions of an English Opium Eater (1822) was able to discern marked similarities between the Carceri and his own drug-induced hallucinations, remarking: "With the same power of endless growth and selfreproduction did my architecture proceed in my dreams." 2 They appealed also to French poets such as Gautier, Baudelaire and Victor Hugo, the latter incorporating a description of the 'Prisons' in a cycle of poems aptly entitled Les Rayons et les Ombres:

Devant vos profondeurs j'ai pâli bien souvent

Comme sur un abîme ou sur une fournaise,

Effrayantes Babels que rêvait Piranèse ... .

In the present century Aldous Huxley, in his essay Prisons, has been largely responsible for the popular linking of the Carceri not only to the anonymous efficiency of bureaucratic institutions, but also - and perhaps more significantly - to the horrors of the mind: 
Yale University Library", Modern Austrian Literature 5 (1972), Nr. 3/4, S. 39, Titel Nr. 68, 13). Veröffentlicht wurde er zuerst in: Hermann Broch, Zur Universitätsreform. Hrsg. und mit einem Nachwort versehen von Götz Wienold. Frankfurt a.M. 1969 (edition suhrkamp 301), S. 78 - 114. Jetzt auch in: Hermann Broch, Massenwahntheorie. Beiträge $z u$ einer Psychologie der Politik. (Kommentierte Werkausgabe, hrsg. von Paul Michael Lützeler, Bd. 12). Frankfurt a.M. 1979, S. 11 - 42. Der Abdruck dort ist mit folgender Anmerkung versehen:

"Im Frühjahr 1939 stellte Broch diesen 'Vorschlag' fertig. Es handelte sich dabei um die Ausarbeitung einer Idee, deren Realisierung Broch erstmals in seiner 'Völkerbund-Resolution' von 1937 vorgeschlagen hatte. Er schickte diese Projektstudie u. a. an das Institute for Advanced Study, Princeton, zu Händen von Albert Einstein und an Alvin Johnson, Direktor der New School for Social Research, New York City. Beide ermunterten Broch, den in der Studie umrissenen Fragestellungen selbst nachzugehen. Einstein sprach sich gegen eine besondere Institutsgründung aus, aber er vermittelte in den folgenden Monaten Brochs Kontakt zum Office of Public Opinion Research der Princeton University."

Oesers Exemplar, nach dem hier zitiert wird, umfaßt 23 Seiten, dazu das im Brief vom 30. 7. 1939 erwähnte Einlageblatt 4A, das zwar nach dem Erhalt von Oesers Brief versendet wurde, aber vermutlich schon vorher fertig war und jedenfalls von dessen Kritik offenbar unbeeinflußt ist.

13 Eric Herd im Vorwort zu den Briefen an Willa Muir in:

Gesammelte Werke, Bd. 10, Zürich 1961, S. 313.

14 Vgl. Gesammelte Werke, Bd. 10: Die Briefe an Willa Muir. Hrsg. von Eric Herd, Zürich 1961, S. 369.

15 Vgl. Gesammelte Werke, Bd. 9: Massenpsychologie, Zürich 1959, S. 15 und $77 \mathrm{ff}$.

16 Vgl. z. B. die Rezension des Bandes "Massenwahntheorie" der Kommentierten Werkausgabe, Frankfurt a.M. 1979, Literatur und Kritik, Nr. 138 (September 1979), S. 500 - 501 (Klaus Amman). 
All the plates in the series are self-evidently variations on a single symbol, whose reference is to things existing in the physical and metaphysical depths of human souls - to acedia and confusion, to nightmare and angst, to incomprehension and a panic bewilderment. ${ }^{3}$

It is in this tradition that Hans Magnus Enzensberger has placed himself with his two attempts to express the mystery of the Carceri: in carceri d'invenzione, a poem from the volume blindenschrift (1964); ${ }^{4}$ and in G.B.P. (1720-1778), one of the thirty-seven Mausoleum ballads of 1975.5 In the first poem Enzensberger made a double interpretation, but in the second he admitted as many as seven, confining himself to no single one. Before proceeding to examine the poems in detail, however, considerable attention must be devoted to the etchings themselves, their origin, their nature and what commentators have made of them - since Enzensberger presupposes a certain familiarity with the Carceri.

The Carceri d'Invenzione exists in two editions. It is thought that Piranesi commenced work on them as a young man in approximately 1745 , and the first state appeared in about 1750 with the publisher Bouchard as a set of only fourteen etchings. 6 Some ten years later, in 1761, he produced a revised edition with two additional plates (II and V) and substantial alterations to those already in existence. Where the plates in the first state show signs of great haste, even a creative frenzy, in their roughness and mere suggestion of forms and figures, in the second numerous details are added or made more explicit, and the contrast between light and darkness is sharpened, rendering the atmosphere more sinister and more mysterious. Since Enzensberger stresses this contrast in both his poems and also dwells on details not so readily apparent in the first state, we shall characterize only the etchings of the second state here.

Despite being 'variations on a single symbol', as Huxley claims, each plate retains enough individuality to hamper accurate generalizations about the series as a whole. It may appear, for instance, that they depict a subterranean or at least a completely enclosed environment; and yet plates II, IV and V allude quite explicitly to the external world with their portrayal of towers and cloudy skies. However, there is a dominant impression conveyed by the Carceri: this is of a claustrophobic and infinite maze of stairs, galleries, beams and masonry, grilles which bar the way not to freedom or to fresh air, but to an even darker and more suffocating dungeon. These prisons are peopled by tiny faceless figures, who either play the role of gesticulating observer or are suffering cruel punishments for undisclosed crimes.In several of the plates evil-looking machines are at work, winches and pulleys operating to inflict torture or in the service of some unspecified industry.

Because of their mysterious and ambiguous nature the Carceri have invited a multitude of often conflicting interpretation. On the simplest level they 
have been explained as a symptom of fever or of an indulgence in laudanum, even of psychological disorder: to de Quincey they "record the scenery of (Piranesi's) visions during the delirium of fever", 7 a reading echoed by an early 20th century commentator, Arthur Samuel; 8 Hans Volkmann assumes that they are a result of "seelische Depressionen"; 9 even Marguerite Yourcenar, one of the most perceptive and creative writers on the Carceri, accepts the delirium of malaria as the initial impulse for the series, but she does not content herself with this explanation. Somewhat more sophisticated is Huxley's appreciation of the Carceri as "metaphysical prisons", 10 as an expression of "states of the soul"11 and even of the "colossal pointlessness"12 of human existence. Modern art historians, however, are quick to discount such theories, or at least to consider them as less than sufficient, seeking more easily corroborated influences. Jonathan Scott, for instance, stresses that to view the Carceri "solely in terms of psychological disorder is easy, exciting and wrong. Piranesi was not a manic depressive reproducing images of the collective unconscious in drug addicted spasms of creation." 13 Instead Scott and others are concerned to highlight specific facets of the Carceri and the close relationship they bear to Piranesi's interests elsewhere, such as his knowledge of stage-design, his background as an architect.

It is considered very likely that Piranesi received a training in stage-design, since he went to work with Carlo Zucchi, an expert in the field, during his youth in Venice. In the 18th century Venice was noted for its theatres; but as A. Hyatt Mayor affirms, "the many opera-houses in that pleasure resort did not attract their international audiences by well-written plays, but by the ingenious contrivance of their scenery." 14 Piranesi would have been familiar with the work of Ferdinando Bibiena, who pioneered new perspectives in stage-design, and with that of Filippo Juvarra, whose influence may be traced in the Carceri. ${ }^{15}$ Such artists created sets which suggested the monumental, "backdrops painted with endless flights of balustraded stairs and domes beyond domes", 16 and included in their repertoire designs for the prison-scenes popular in the plays and operas of the time. It is thus possible to regard the Carceri as stage-designs of a particularly gloomy and phantastic nature. One must also take into account the fact that Piranesi was originally an architect, indeed he came from a family of stone masons on his father's side and of architects on his mother's. Owing to a general lack of public or private funds Piranesi, despite his reputation, was never commissioned to carry out any major architectural work, and consequently it seems legitimate to assume that the Carceri and much of his other work served as "an outlet for (his) frustrated architectural imagination".17 One further element which no doubt fired his creative mind, particularly with regard to the second state of the 'Prisons', was his archaeological fascination with underground structures, the buried cisterns at Castel Gandolfo, for instance, or the subterranean rooms of Hadrian's villa at Tivoli. 
We do not know the extent of Enzensberger's reading on Piranesi and his 'Prisons', but in the index to Mausoleum he does include an entry for Marguerite Yourcenar, the French novelist, who wrote Die imaginären Gefängnisse des Piranesi, an important essay first published in German in 1961. A close reading of this essay gives a clear indication of the direction which Enzensberger takes in his two poems. Yourcenar's approach to the Carceri is fundamentally a psychological one, aspects of which have been touched on earlier. She concurs with Huxley in her view of the series as a depiction of 'das Gehirn des Menschen' and its infernal workings:

Diese Stätten der Abgeschlossenheit, aus denen die

Zeit und die Formen der lebendigen Natur verbannt

sind, diese geschlossenen Räume, die so rasch zu

Folterkammern werden, deren Bewohner sich aber in

der Mehrzahl offenbar auf eine gefährliche und

stumpfe Art wohl fühlen, diese Abgründe ohne Boden

und ohne Ausweg sind nicht irgendein Gefängnis: sie sind unsere Höllen. ${ }^{18}$

This, as will become evident, provides Enzensberger with a starting-point for the earlier of his two poems, carceri d'invenzione. However, Yourcenar's influence does not limit itself to generalities. In his ballad from Mausoleum, G.B.P. (1720-1778), Enzensberger goes so far as to incorporate one of her insights and even to quote directly from the German translation of her essay. This occurs in the fourth section, entitled 'Folter und Industrie', in which the ambiguity of the machines depicted in some of the Carceri is stressed, an ambiguity which is explained by both Yourcenar and Enzensberger (using her words) in the phrase, "die Ähnlichkeit zwischen den Folterinstrumenten einer Epoche und ihren technischen Werkzeugen".19 Two further details which Enzensberger appears to have gleaned from Yourcenar are the description of the inhabitants of the Carceri as 'Mücken' and of the manner in which they deport themselves. In Yourcenar's essay we find the sentence: "Diese Mücken, die sich leicht und wohlgemut in wahnwitzigen Höhen tummeln, scheinen nicht wahrzunehmen, daß sie sich am Rand des Abgrunds bewegen".20 Enzensberger uses the term 'Mücken' in section II of G.B.P. (1720-1778) and in section I provides a strikingly similar representation of the figures' movement: "Das Licht, in dem sie über die Treppen taumeln, ist ungewiß, und es scheint, als bewegten sie sich, Seiltänzer, ohne es zu ahnen, am Rand eines Abgrunds." It would seem, therefore, that Enzensberger's understanding of the Carceri owes more than a little to Marguerite Yourcenar.

In the poem carceri d'invenzione, which, significantly, is included in the section of blindenschrift entitled 'camera obscura', Enzensberger maintains a fundamental ambiguity between the representation of a prison and of 'das Gehirn'. He does this by the ingenious, simultaneous employment of terms 
which relate to both architecture and the anatomy of the brain. In fact, when the poem was selected for the later volume Gedichte 1955-1970, Enzensberger added the following sentence to the brief explanatory note about the poem's title already included in blindenschrift: "Die im Text erscheinenden Bestandteile der Gewölbekonstruktion sind zugleich Termini aus der Anatomie des Gehirns."21 Thus the new dimension specifically added by Enzensberger to our appreciation of the Carceri is an anatomical one, which is in turn peculiarly relevant to Huxley's and Yourcenar's conception of them as representations of the psyche. However, the parallel between the two notions of 'Gefängnis' and 'Gehirn' does not confine itself to semantics: seizing on the visual impact of the Carceri Enzensberger concentrates largely on the stark contrast between darkness and light and hints at the same time that this contrast is a quality shared by the functioning of the human brain and our knowledge of it.

The language which Enzensberger uses in this poem is clear, yet obscure, and thus conforms to the general atmosphere of ambiguity. This is apparent not only in the dual-purpose vocabulary of anatomy and architecture, but also in the deceptive simplicity of syntax and the frequent utilization of paradox. The simultaneous description of the prisons and of the brain is established in the opening line of the poem, where 'gewölbe' signifies the vault of both a building and of the skull ('Schädelgewölbe'); the connection is then further strengthened in lines eight to thirteen, where 'höhlen', 'gruben', 'spalten', 'galerien', 'balken' and 'brücken' all have specific anatomical meanings - 'Höhle', for example, being a 'ventricle' and 'Balken' the 'corpus callosum' of the brain - as well as the more orthodox architectural application. The simplicity of the syntax derives from the apparent use of ellipses - 'diese gewölbe', 'blitze ohne himmel' etc. - and the almost total lack of subordinate clauses, exceptions being in lines fourteen-fifteen and twenty-one to twenty-three. Yet a closer examination reveals that the poet is not employing ellipses, but is gathering multiple subjects for the infrequent verbs. Thus in the first seven lines 'gewölbe', 'blitze', 'strahlen', 'höhlen', 'gruben' and their accompanying phrases are all linked to 'beherbergen'; similarly, in the last seven lines 'gewölbe' and 'häupter' are the joint subject of 'sind', balanced by the contrast between 'geträumt' and 'träumend' and both relating to the complement 'undurchdringlich'. So through the very ambiguity of the syntax the reader is steered at the conclusion towards making the identification intended by the poet between Piranesi's prisons and the brain. But it is perhaps the series of paradoxes in the poem which conveys most effectively the confusing and mysterious world of the Carceri, for the latter may be regarded in themselves as visual paradoxes. Most of Enzensberger's paradoxes relate to properties of light and darkness, either in the literal or figurative sense: 'dunkel hell dunkel', 'blitze ohne himmel', 'strahlen ohne gestirn', 'weder tag noch nacht', 'vernünftig und rätselhaft', 'schlaflose träumer', 'gefangene/nicht besiegte'. And it is because of this deliberate mixture of the literal and figurative that it becomes possible to move 
from the light and darkness, the compelling yet impenetrable nature of the Carceri, to our imperfect understanding of the human mind, with its flashes of genius and its obscure, irrational cogitations - a step made explicit in the last three lines:

\section{undurchdringlich}

sind

unsere träumenden häupter 22

Although G.B.P. (1720-1778) does not display the orthodox outer manifestations of a 'poem', it is designated a 'ballad' by Enzensberger - its very presence in Mausoleum confirms this - and it features at least one characteristic normally associated with poetry: a refrain, which revolves round the phrase 'wissen wir nicht' and appears at the end of the first half of each of the six sections. G.B.P. is in many respects a more complex poem than carceri d'invenzione, drawing on a much more detailed knowledge of Piranesi, the Carceri and of the 18 th century in general. Yet at the same time it is simpler, in that it presents its views of the Carceri in a clear-cut, even logical manner, not compressed in verbal ambiguity. If we accept that the section entitled 'Folter und Industrie' contains two possible interpretations of the 'Prisons', then the ballad may be said to present seven views in all, of which one (V Das Gehirn) deals more explicitly with material already encountered in the earlier poem, and all of which appear to be rejected. The rejection is made explicit not only in the refrain, with its admission of bewilderment, but also in the direct address of the lyrical self to the 'du' - specifically the reader: "Entscheide nun selbst, Leser, ob es Kavaliere sind. . ." Thus we find in the second section that the assumption of the first - that the Carceri embody stage-designs - has been discarded: "Was du auf diesen Bildern siehst, das sind keine Kulissen"; and in section V the reader is bluntly informed: "Du irrst dich in diesen Stichen". That it is in fact the Carceri which this ballad is primarily directed towards, and not Piranesi's entire oeuvre, is borne out by a number of references which could allude to nothing else, that is, their claustrophobic, infinite and puzzling nature: "denn dieses Innen aus Stein hat kein Außen"; "Erkennst du denn nicht, daß dieser Raum zwar geschlossen, aber unendlich ist?"; "In diesen Augentäuschungen ... verlierst du dich."

The first approach taken towards the Carceri in G.B.P. is to see them in theatrical terms, an approach consistent with that of several art historians: they are said to represent a single, gigantic stage on which an unknown play is being performed. However, the main emphasis in the first section is on the figures ('die Spieler, Liliputanern gleich'), who are accurately described as being dwarfed out of recognition by the set in typical Piranesi fashion. The suggestion is that, although they might be individuals of flesh and blood "Kavaliere . . . Kurtisanen, Müßiggänger und Hasardeure, Figuren aus dem Theater Goldonis" - they are more likely to be marionettes - 'Kunstfiguren, 
Puppen, mechanische Spielzeuge' - the passive victims of manipulations beyond their comprehension and control. The very title of section I (Die Marionetten) lends weight to this supposition. The second half of this section switches, as it does in all others but section VI, to a wider, historical perspective: a brief, biographical account of Piranesi's move from Venice to Rome in the 1740's. It is interesting that the theatre motif is echoed in the extravagances of the dying republic of Venice and in the very theatrical equipment designed by Piranesi. Also significant is the description of Rome as 'finster, schmutzig, eng' - since these are qualities of the city which emerge in much of Piranesi's work - and the mention of 'Bucklige, Krüppel und Bettelmönche'. The latter fascinated Piranesi, appealing to his fondness for the grotesque, and found, often quite gratuitously, a place in many of his plates.

'Die Archäologie', the second approach, introduces a measure of uncertainty, in that the features described would seem to relate more closely to the Roman ruins investigated by Piranesi than to the Carceri. This is particularly evident in the terms 'Tempel und Aquädukte, Thermen und Kolonnaden' and the classification of the inhabitants as 'Bettler, Wäscherinnen, Gassenkinder', all of which indicate a precision which is not present in the Carceri. Piranesi himself was responsible for the discovery and close examination of several important ruins, including much of the Roman aqueduct system, and he also promoted with great vehemence the mistaken theory that Roman architecture was founded on Etruscan and not Greek principles. ${ }^{23}$ Perhaps it is the latter aspect which is being alluded to in the statement: "Aus dem Steinbruch der Geschichte löst sich ein Strom von Fälschungen." But it is also clear from the context that 'Fälschungen' is more relevant to the lucrative business of dealing in antiquities, which proliferated at the time and was engaged in by Piranesi, amongst others. The reason as to why Enzensberger breaks the sequence somewhat in this section II by virtually overlooking the Carceri themselves may relate to the notion, already suggested, that much of the inspiration for the series came from Piranesi's deep interest in underground structures; and these, if not the "Prisons", are in evidence here.

Section III, entitled 'Carceri d'Invenzione', provides the most literal approach, with a vivid description of the etchings as unfathomable dungeons transforming the world into 'ein Zwinger, eine Bastille' where the prisoners are observed by warders made minute by the height of their vantage points. In the statement "Ein Jahrhundert, das an Befreiung denkt und Gefängnisse phantasiert", Enzensberger is pointing out the discrepancy between the rising tide of liberal democracy in the 18 th century which culminated in the French Revolution and the impulses which led Jeremy Bentham, for example, to design his 'perfectly efficient prison', the so-called panopticon. 24 It has even been suggested that George Dance was strongly influenced by Piranesi in his design of the infamous Newgate prison. 25 Significantly, this section also closes with a catalogue of the outcasts and infirm who appealed so strongly to Piranesi's 
imagination.

Enzensberger's debt to Marguerite Yourcenar in section IV, 'Folter und Industrie' has already been established. Here he accounts for the machinery and puzzling activity evident in some of the Carceri, moving from the assumption that they represent a 'Werkstatt' or a 'Schmiede' to the suspicion that the purpose is far more sinister: "und jene hölzernen Konstruktionen - ob es Bau - oder Blutgerüste sind, das wissen wir nicht." The second half develops this last thought and proceeds to enumerate, in words taken from an undisclosed source, the degrees of torture applied in German courts during and beyond the 18 th century.

With section V, 'Das Gehirn', attempts at literal interpretation are abandoned, and the Carceri are explained as an expression of the infinite labyrinth of consciousness. As in the earlier poem from blindenschrift the contrast between light and darkness is emphasized - "Auf die Strahlen und Schatten mußt du achten, sie kündigen etwas anderes an" - and, as the refrain intimates, our knowledge of the brain is imperfect: it is, in the phrase of the earlier poem, 'undurchdringlich'. Enzensberger then links this approach with the work of the early anatomists, Malpighi, Vicq d'Azyr, Haller and Reil, all but the first of whom were contemporaries of Piranesi; and the identification between anatomical and architectural terminology, with which we are already familiar, is made - but here in an explicit manner. This section also connects with the very first in its use of the theatre motif - "Auch die Anatomie hat ihr Theater" - and serves as a summary for what has been communicated before - in the list "Gehirnforscher, Menschenfreunde, Folterknechte, Archäologen und Puppen". It concludes with an ingenious comparison between the instruments of the anatomist and those of the engraver.

'Die Halluzination', the sixth and shortest section, resorts - in utter bewilderment, it seems - to the unsophisticated elucidations of de Quincey and Arthur Samuel: "Es ist ein Fieberwahn, ein Delir". Here there may be an implicit link with the word 'verrückt' from Piranesi's famous statement which ends the ballad: "Ich glaube, wenn man mich mit dem Plan für ein neues Universum beauftragen würde, ich wäre verrückt genug, mich daran zu machen." A more important link, however, is that between the surmise, "Was du auf diesen Stichen siehst, ist eine andere Welt" and Piranesi's own 'Plan für ein neues Universum'. For, in view of the multitude of differing interpretations, the fact that each generation can find new meaning in the Carceri, it does not seem far-fetched to claim that 'ein neues Universum', with its myriad and mostly sinister facets, is precisely what Piranesi intended to represent in these etchings.

Before leaving G.B.P. (1720-1778) and discussing the wider implications of Enzensberger's fascination with the Carceri, a note on this poem's place amongst the other Mausoleum ballads would seem in order. Mausoleum is subtitled 'Siebenunddreissig Balladen aus der Geschichte des Fortschritts' and it is thus 
evident that all of the ballads are linked by a common theme, that of 'progress'. The volume consists of thirty-seven separate 'lyrische Biografien'26 of historical personages, who, in the poet's opinion, are responsible for decisive contributions to the history of progress. A broad range of achievements is covered, in astronomy, politics, engineering, medicine, economics, even conjuring, and names familiar to the 20 th century reader - Machiavelli, Leibniz, Darwin - are numbered side by side with the not so familiar - Giovanni de' Dondi, Lazzaro Spallanzani, Alan Mathison Turing. However, it is not the individual figures who play the main role in this volume, but the more abstract historical process in which they are involved and to which they give flesh and blood. It is this overriding historical link which caused the author to give each figure the anonymity of titles offering only their initials and dates, their full identity being revealed in the index. For Enzensberger the march of progress is very much a two-edged concept: on the one hand he does not ignore "die produktiven, befreienden Anstöße für die Menschlichkeitsentwicklung", as Michael Franz puts it, 27 in the work of Gutenberg and Semmelweis, for instance; but on the other he demonstrates repeatedly how significant discoveries and inventions have led to abuses and selfish exploitation. The last words of the very first ballad, G.de'D (1318-1389) are in this sense prophetic:

In diesem Mittelalter

leben wir immer noch. 28

and the list of evils stretches from the cynical application of Machiavelli's theories to the callous administering of shock therapy. The damage wrought by Piranesi's work is not explicitly defined in the ballad; yet there are a number of hints that his etchings at least reflected much of the cruelty and injustice of his time, and foreshadowed something of what was to come, even if they did not exercise an adverse influence in themselves. We can distinguish in Enzensberger's poem the anonymous manipulations of the modern state - in the passive marionettes of section I, the prisoners and warders of section III, the torture instruments of section IV; we can also discern the nightmares of the Industrial Revolution in section IV; and finally in section II the beginnings of commercialized tourism and dealing in antiques are shown in a rather negative light. In G.B.P. (1720-1778) the ambiguities of progress which form the central concern of Mausoleum are faithfully mirrored in the Carceri, which introduce in turn ambiguities of their own.

To fit Enzensberger's ballad on Piranesi into the general context of Mausoleum does not, however, supply a satisfactory motivation for the fact that the poet has on two occasions felt impelled to tackle the problem of the Carceri. To discover this motivation it is necessary to indulge in a little speculation. As has been demonstrated, the abiding interest in the Carceri has arisen from the ambiguities they generate, not only in content, but even in their composition. 29 It is also true that ambiguity and its adjuncts, paradox and contradiction, 
are at the very core of Enzensberger's philosophy and art. Consequently, the mysterious visions of the 18th century Italian artist must have found not only a ready appreciation in the 20th century German poet, but also provided an 'objective correlative', as it were, for the expression of his own inner nature.

The ambiguity in Enzensberger's nature originates in his political standpoints and penetrates ultimately to the structure of his poems, his very use of language. The central dichotomy in Enzensberger's political awareness has been aptly summed up by the East German critic Dieter Schlenstedt as "(der) Zwiespalt. . . zwischen dem Wunsch nach Aktivität und der Erfolglosigkeit der Bemühungen".30 Enzensberger launched his considerable reputation as a poet on the strength of the angry and bitterly satirical verse in the third section of verteidigung der wölfe, poems such as bildzeitung, geburtsanzeige and the title poem itself. In this capacity he became associated with various political causes, including the question of military and nuclear cooperation between the Federal Republic of Germany and South Africa ${ }^{31}$ and, most prominently, the student uniest of the late 1960's. But there has always been another side to this active commitment, a side of resignation and scepticism, which is apparent from his earliest work, in the words "was du tust, ist aussichtslos", from the poem anweisung an sisyphos, 32 to his withdrawal to the unpeopled landscape dominant in the volume blindenschrift. Even in Mausoleum there seems to be a grudging acceptance of the fact that history - and the political events it occasions - is a meaningless cycle which can neither be altered nor steered by human agents. The dilemma is a complex one, which cannot be pursued further here, except to add that it is matched by a corresponding uncertainty as to whether poetry itself has any useful political function or not. What is relevant here is that the dilemma has never been satisfactorily resolved and the poet seems to have developed as a result of his uncertainty an intellect which is elusive, chameleon-like.

The poetic consequences of the dichotomy are varied, but three in particular may be selected. One device which Enzensberger frequently resorts to, in order to structure a poem, is to employ the motif of the 'Doppelgänger', 33 whereby he projects one side of an internal conflict onto an external protagonist. Perhaps the most effective example of such a poem is lachesis lapponica, ${ }^{34}$ in which a dialogue is conducted between the lyrical self and an impertinent 'vogel in meinem .kopf', the former advocating a state of isolated resignation, the latter urging political involvement of an indeterminate kind. Enzensberger also exhibits a fondness for paradox, the juxtaposition of elements normally at variance with one another; again this would appear to be a symptom of dividedness in the poet's nature. Its application extends from single instances, such as "Die Vergangenheit wird gerettet, geplündert" from G.B.P. to a central paradox on which a whole poem may pivot. An instructive example of the latter is abgelegenes haus, ${ }^{35}$ a poem which turns on the statement "die stimme des schreckens/beruhigt mich" - a paradox which sums up the poet's ambivalent 
feelings towards his status as a social and political being.

But what for our purposes is perhaps the most significant poetic corollary to Enzensberger's dilemma lies in the abrupt swings between lucidity and obscurity which may be registered in his work. There appears to be some theoretical basis for this phenomenon, for in Scherenschleifer und Poeten, a brief essay written in 1961, we find the statement:

Zwischen Hyperbel und Andeutung, Übertreibung und Understatement, Ausbruch und Ironie, Raserei und Kristallisation, äußerster Nähe zum glühenden Eisen des Gegenstandes und äußerster Entfernung von ihm fort zum Kältepol des Bewußtseins ist die Sprache einer unausgesetzten Probe zu unterziehen. 36

Enzensberger is alluding here not only to the multiplicity of language which may be mobilized in a poem, but also to two quite distinct poetic approaches to a given subject or "Gegenstand'. Extreme proximity ("äußerste Nähe") to the subject produces a poem which reflects untempered emotion, expressing itself directly, transparently. Extreme distance ("äußerste Entfernung") on the other hand presupposes the cooler experience of an emotion, which affords the poet the opportunity to handle the subject obliquely and opaquely. The distinction may be observed at work in a pair of poems which treat similar 'Gegenstände': sozialpartner in der rüstungsindustrie, 37 an early, 'angry' poem, and the ironic Beschreibung eines Dickichts, 38 first published a decade later. Common to both is Enzensberger's familiar theme of political apathy, but where in the first poem this may be easily perceived:

verdorben, jeder nasführung aus-

geliefert, ein hut voll mutlosen winds,

eigener handschellen schmied,

geburtshelfer eigenen tods ...

in the second it is concentrated in the image of the 'Dickicht' which is unfolded in a series of six variations, but nowhere directly elucidated. Instead the reader must extrapolate from the context and from his understanding of a 'Dickicht' as a confusion of greenery which hinders vision to the political blindness and confusion of society at large. It is as if in sozialpartner. . Enzensberger hopes to shock the reader with a direct attack into a meaningful political reaction, whereas in Beschreibung eines Dickichts he is content to make a veiled and resigned statement about a general lack of political awareness.

To return from this excursion on Enzensberger's work in general to his preoccupation with the Carceri, it may be concluded that in the earlier of the two Piranesi poems he found a suitable opportunity to unite the two impulses of lucidity and obscurity. It has been stated before that the language is clear, yet 
obscure, and as such it reflects not only the visual properties of the etchings, but also their very essence, which is 'vernünftig und rätselhaft'. At the same time Enzensberger's own ambiguous stance would seem to achieve a distillation in his poem carceri d'invenzione, being then translated into a wider historical sphere in the volume Mausoleum, which by no small coincidence also contains a ballad devoted to the shadowy world of Giovanni Battista Piranesi.

\section{Notes}

1 The Mind and Art of Giovanni Battista Piranesi, London 1978, p. 126.

2 Quoted by Arthur M. Hind, Giovanni Battista Piranesi. A Critical Study, London 1967, p. 11.

3 Prisons, with the "Carceri" Etchings by G.B. Piranesi, London 1949, p. 21.

4 (edition suhrkamp 217) Frankfurt a.M. 1965, pp. 26-27.

5 Frankfurt a.M. 1975, pp. 36-39.

6 Hind, pp. 11-12.

7 Ibid., p. 10.

8 Piranesi, London 1910, p. 105: "... a set of designs fashioned in Piranesi's mind during a delirium of fever."

9 Piranesi, Architekt und Graphiker, Berlin 1965, p. 27.

10 Huxley, p. 16.

11 Ibid., p. 18.

12 Ibid., p. 22.

13 Piranesi, London 1975, p. 57.

14 Giovanni Battista Piranesi, New York 1952, p. 4.

15 Scott, p. 47.

16 Hyatt Mayor, p. 4.

17 Wilton-Ely, p. 81. This notion is considered in some depth by Ulya Vogt-Göknil, Giovanni Battista Piranesi. 'Carceri', Zürich 1958, who treats the Carceri "als eigentliche architektonische Ideen" (p. 16) and claims that they are the work of "ein leidenschaftlicher, ja besessener Architekt", for whom "die Zeichnung. . zum Architektur-Ersatz (wird)" (p. 51).

18 "Die imaginären Gefängnisse des Piranesi", Merkur 15 (1961), Heft 15, pp. 1127-1128.

19 Yourcenar, p. 1124. 
20 Ibid., p. 1126.

21 Gedichte 1955-1970, Frankfurt a.M. 1971, p. 173.

22 It is possible that in employing the word 'Haupt' here, and not the more clinical term 'Gehirn', Enzensberger is looking beyond the confines of the Carceri to the sphere of politics. For in a figurative sense 'Haupt' can mean 'leader', and perhaps the last three lines express bewilderment, therefore, at the self-deception of political leaders. However, the use of 'Haupt' can also be explained by its conjunction with 'träumend' to form the assonance of 'träumende häupter', with its suggestion of confusion and even of the infinite.

23 See Scott, Chapter Six: 'The Greek Controversy'.

24 See Huxley, p. 13.

25 Samuel, p. 113.

26 Michael Franz, "Hans Magnus Enzensberger: Mausoleum", Weimarer Beiträge XXII (1976), Heft 12, p. 126.

27 Ibid., p. 132 .

28 Mausoleum, p. 8.

29 As Scott, p. 55, points out, there are, for instance, spatial irregularities such as an impossible flight of stairs in plate XIV.

30 "Die schwierige Arbeit des Hans Magnus Enzensberger," NDL 13 (1965), Heft 7, p. 151.

31 See H.M. Enzensberger, "Brief an den Bundesminister für Verteidigung, Herrn Kai-Uwe von Hassel", in Deutschland, Deutschland unter anderm, Frankfurt a.M. 1967, pp. 27-36.

32 verteidigung der wölfe, Frankfurt a.M. 1957, p. 70.

33 For a fuller treatment of this motif, see William S. Sewell, "Doppelgänger Motif and Two-Voiced Poem in the Work of Hans Magnus Enzensberger", GQ LII (1979), No. 4, pp. 503-517.

34 blindenschrift, pp. 76-79.

35 Ibid., pp. 12-13.

36 Mein Gedicht ist mein Messer, ed. Hans Bender, Heidelberg 1961, p. 146.

37 verteidigung der wölfe, p. 84.

38 Gedichte 1955-1970, pp. 132-133. 